Supporting Information

\title{
Tuning biradical character to enable high and balanced ambipolar charge transport in a quinoidal $\pi$-system
}

Zhaohang Lin, ${ }^{\dagger, \S}$ Li Chen, ${ }^{\ddagger}, \S$ Qiang Xu, ${ }^{\ddagger}$ Guangwei Shao, ${ }^{\dagger}$ Ziyue Zeng, ${ }^{\dagger}$ Di Wu, ${ }^{*}, \dagger$ and Jianlong $\mathrm{Xia}^{*}, \dagger, *$

${ }^{\dagger}$ School of Chemistry, Chemical Engineering and Life Science, Wuhan University of Technology, Wuhan 430070, P. R. China

\$State Key Laboratory of Advanced Technology for Materials Synthesis and Processing, Center of Smart Materials and Devices, Wuhan University of Technology, Wuhan 430070, P. R. China 
Table of Contents

1. General information.......................................................... 2

2. Material synthesis....................................................... 2

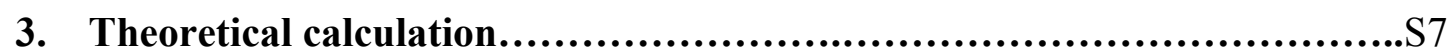

4. Variable-temperature NMR experiment.....................................S7

5. SQUID measurement...................................................... 8

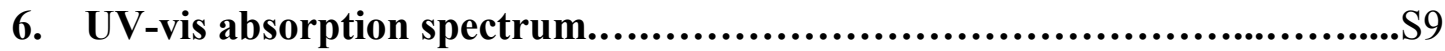

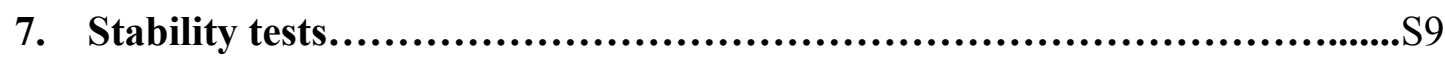

8. OTFT device fabrication and performance...............................S10

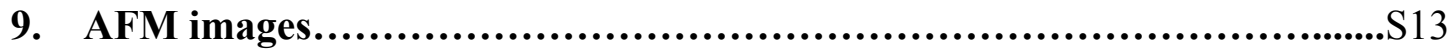

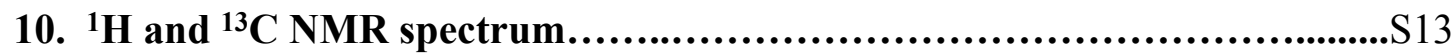

11. MALDI-TOF Mass spectrum...................................................S19

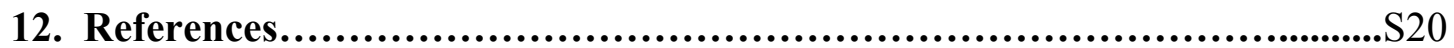




\section{General information}

\section{Chemical reagents and instrument}

Common solvents and starting materials were purchased from commercial sources without further treatment unless specially noted. All chemical reactions were conducted in oven-dried or flame-dried glassware. Unless otherwise specified, the heating reaction were heated in oil bath. ${ }^{1} \mathrm{H}$ NMR and ${ }^{13} \mathrm{C}$ NMR spectrum were measured on Bruker DRX 500 or Varian Mercury plus-400. MALDI-TOF Mass spectrum was measured with AB Sciex 5800. The microwave reactions was accomplished in the sealed vial on the Initiator+ from Biotage. The magnetic susceptibility was measured with MPMS XL-7 Quantum Design SQUID magnetometer in the temperature range of 2-350 K. UV-Vis spectrum was recorded on Shimadzu UV-1800 or Shimadzu UV-3600 plus. Electrochemical analysis of the compounds in dichloromethane was carried out by cyclic voltammograms (CVs), which obtained on a CHI660E electrochemical workstation. A three-electrode one-compartment cell containing a solution of the analyte and supporting electrolyte (tetrabutylammonium, $\left.\left(\left[\mathrm{NBu}_{4}\right] \mathrm{PF}_{6}\right), 0.1 \mathrm{M}\right)$ in dry $\mathrm{CH}_{2} \mathrm{Cl}_{2}$ was utilized. The three-electrode were a $500 \mu \mathrm{m}$ diameter platinum-disk as working electrode, a platinum-wire as counter electrode, and an $\mathrm{Ag} / \mathrm{AgCl}$ as reference electrode. The measurements were obtained under a scanning rate of $100 \mathrm{mV} / \mathrm{s}$. We calculated LUMO levels from the onset wave reduction potential using the ferrocene/ferrocenium $\left(\mathrm{Fc} / \mathrm{Fc}^{+}\right)$couple as a standard.

\section{Material synthesis}

\subsection{Synthesis of QBDT (Compound 3)}

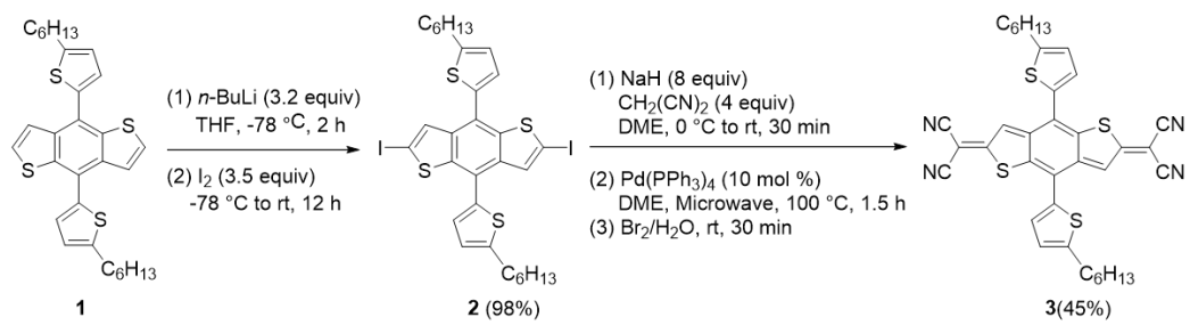

Scheme S1. Synthetic route of QBDT (Compound 3). 
Compounds 1 was prepared according to a literature procedure. ${ }^{[\mathrm{S} 1]}$

\section{Compound 2.}

\section{4,8-bis(5-hexylthiophen-2-yl)-2,6-diiodobenzo[1,2-b:4,5-b']dithiophene.}

Compound 1 (520.49 mg, $1 \mathrm{mmol}$ ) was dissolved in anhydrous THF (50 mL) under nitrogen atmosphere and was cooled to $-78{ }^{\circ} \mathrm{C}$, then $n$-butyllithium $(2.00 \mathrm{~mL}, 3.20$ mmol, $1.60 \mathrm{M}$ ) was added dropwise via syringe under stirring and the solution turned to green. After stirring at this temperature for $2 \mathrm{~h}$, Iodine $(888 \mathrm{mg}, 3.50 \mathrm{mmol})$ was added and the mixture was stirred at $-78^{\circ} \mathrm{C}$ for another $0.5 \mathrm{~h}$. The reaction system was warmed up to room temperature and stirred at room temperature overnight. Water was added to quench the reaction and the reaction mixture was extracted three times with $\mathrm{CH}_{2} \mathrm{Cl}_{2}$. The organic layer was separated and dried over $\mathrm{MgSO}_{4}$. After evaporation of the solvent, the crude product was purified on a silica-gel column chromatography with petroleum ether as the eluent. Compound $2(755 \mathrm{mg}, 98 \%)$ was obtained as a light yellow solid. ${ }^{1} \mathrm{H}$ NMR (500 MHz, Chloroform-d) $\delta 7.77(\mathrm{~s}, 2 \mathrm{H}), 7.21(\mathrm{~d}, \mathrm{~J}=3.5$ $\mathrm{Hz}, 2 \mathrm{H}), 6.90-6.88$ (m, 2H), 2.90 (s, 4H), 1.81-1.73 (m, 4H), 1.48-1.42 (m, 4H), 1.36 (s, 8H), 0.93 (s, 6H). ${ }^{13} \mathrm{C}$ NMR $\left(100 \mathrm{MHz}, \mathrm{CDCl}_{3}\right) \delta 147.77,143.35,137.08,135.95$, 133.11, 127.97, 124.48, 121.56, 80.41, 31.58, 31.56, 30.26, 28.92, 22.60, 14.10 . HRMS (MALDI-TOF) m/z: [M] ${ }^{+}$Calcd for $\mathrm{C}_{30} \mathrm{H}_{32} \mathrm{I}_{2} \mathrm{~S}_{4}$ 773.9476; Found 773.9453 .

\section{Compound 3.}

\section{2,2'-(4,8-bis(5-hexylthiophen-2-yl)benzo[1,2-b:4,5-b']dithiophene-2,6-diylidene)di} malononitrile. (QBDT)

A solution of malononitrile $(51 \mathrm{mg}, 0.77 \mathrm{mmol})$ in anhydrous DME $(10 \mathrm{~mL})$ under nitrogen atmosphere was cooled down to $0{ }^{\circ} \mathrm{C}$, Sodium hydride $(62.2 \mathrm{mg}, 60 \%$ dispersed in mineral oil, $1.55 \mathrm{mmol}$ ) was added to the reaction mixture and stirred for $30 \mathrm{~min}$, and the mixture was warmed up to room temperature. This reaction mixture was transferred into a sealed and degassed $20 \mathrm{~mL}$ microwave vial under nitrogen, the vial was pre-filled with compound $2(150 \mathrm{mg}, 0.19 \mathrm{mmol})$ and $\mathrm{Pd}\left(\mathrm{PPh}_{3}\right)_{4}(22.5 \mathrm{mg}$, 
$0.0194 \mathrm{mmol}$ ). The sealed vial was heated to $100{ }^{\circ} \mathrm{C}$ by a microwave reactor and the temperature were detected by the built-in probe. The reaction were stirred for $1.5 \mathrm{~h}$ in $100{ }^{\circ} \mathrm{C}$. After cooling to room temperature, $3 \mathrm{~mL}$ of saturated bromine water was added and the mixture was stirred at room temperature for $30 \mathrm{~min}$. The resulting mixture was extracted with $\mathrm{CH}_{2} \mathrm{Cl}_{2}$ and washed with water and brine, and dried over $\mathrm{MgSO}_{4}$. After evaporation of the solvent, the residue was purified on a silica-gel column chromatography with $\mathrm{CH}_{2} \mathrm{Cl}_{2}: \mathrm{PE}=2: 1$ to give $55 \mathrm{mg}$ of compound 3 as a purple solid in 45\% yield. ${ }^{1} \mathrm{H}$ NMR (500 MHz, Chloroform-d) $\delta 7.64$ (s, 2H), 7.25 (d, $\mathrm{J}=3.6 \mathrm{~Hz}, 2 \mathrm{H}), 6.97(\mathrm{dd}, \mathrm{J}=2.9,1.9 \mathrm{~Hz}, 2 \mathrm{H}), 2.94(\mathrm{t}, \mathrm{J}=7.7 \mathrm{~Hz}, 4 \mathrm{H}), 1.79$ (p, J = $7.6 \mathrm{~Hz}, 4 \mathrm{H}), 1.46(\mathrm{dd}, \mathrm{J}=10.0,4.8 \mathrm{~Hz}, 4 \mathrm{H}), 1.40-1.35(\mathrm{~m}, 8 \mathrm{H}), 0.96-0.92(\mathrm{~m}, 6 \mathrm{H})$. ${ }^{13} \mathrm{C}$ NMR $\left(100 \mathrm{MHz}, \mathrm{CDCl}_{3}\right) \delta 169.61,151.73,147.11,143.19,131.68,131.37$, $130.57,127.55,125.73,113.24,112.48,74.52,31.48,31.32,30.27,28.87,22.54$, 14.05. HRMS (MALDI-TOF) m/z: [M+H] $]^{+}$Calcd for $\mathrm{C}_{36} \mathrm{H}_{33} \mathrm{~N}_{4} \mathrm{~S}_{4} 649.1583$; Found 649.1598.

\subsection{Synthesis of QTBDT-3H (Compound 7)}

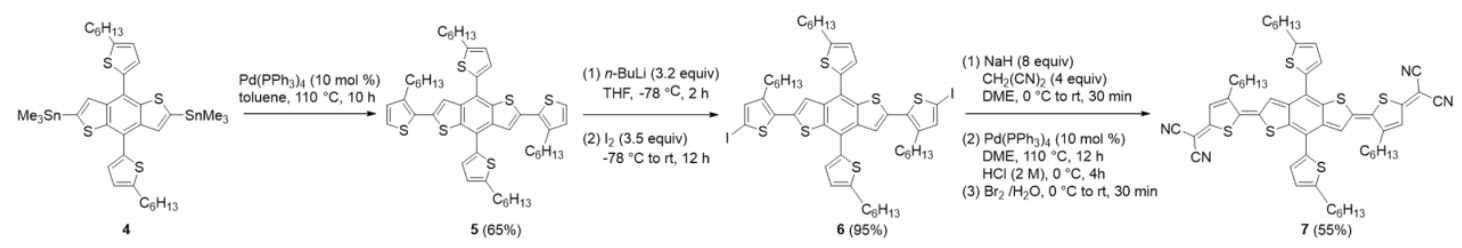

Scheme S2. Synthetic route of QTBDT-3H (Compound 7).

Compounds 4 was prepared according to a literature procedure. ${ }^{[\mathrm{S} 1]}$

\section{Compounds 5.}

2,6-bis(3-hexylthiophen-2-yl)-4,8-bis(5-hexylthiophen-2-yl)benzo[1,2-b:4,5-b']dit

\section{hiophene.}

In a $100 \mathrm{~mL}$ two-neck round bottom flask under ambient atmosphere, compound 4 $(0.732 \mathrm{~g}, 0.863 \mathrm{mmol})$ and 2-bromo-3-hexylthiophene $(0.640 \mathrm{~g}, 2.58 \mathrm{mmol})$ was added. The flash was purged with $\mathrm{N}_{2}$ for $20 \mathrm{~min}$, followed by the addition of $\mathrm{Pd}\left(\mathrm{PPh}_{3}\right)_{4}(100 \mathrm{mg}, 0.0863 \mathrm{mmol})$ and toluene $(50 \mathrm{~mL})$. The resulting mixture was 
then refluxed for $10 \mathrm{~h}$. After cooled down to room temperature, water was added and the resulting mixture was extracted with $\mathrm{CH}_{2} \mathrm{Cl}_{2}$ three times, the organic mixture was washed with brine, and dried over $\mathrm{MgSO}_{4}$. After evaporation of the solvent, the residue was purified on a silica-gel column chromatography with $\mathrm{CH}_{2} \mathrm{Cl}_{2}: \mathrm{PE}=8: 1$. After further crystallization, compound 5 (400 mg, 65\%) was obtained as a light orange solid. ${ }^{1} \mathrm{H}$ NMR (500 MHz, Chloroform-d) $\delta 7.63$ (s, 2H), 7.33 (d, J = 3.5 Hz, 2H), $7.23(\mathrm{~d}, \mathrm{~J}=5.1 \mathrm{~Hz}, 2 \mathrm{H}), 6.95(\mathrm{~d}, \mathrm{~J}=5.1 \mathrm{~Hz}, 2 \mathrm{H}), 6.91(\mathrm{~d}, \mathrm{~J}=3.5 \mathrm{~Hz}, 2 \mathrm{H}), 2.92$ $(\mathrm{t}, \mathrm{J}=7.7 \mathrm{~Hz}, 4 \mathrm{H}), 2.85-2.80(\mathrm{~m}, 4 \mathrm{H}), 1.78(\mathrm{p}, \mathrm{J}=7.7 \mathrm{~Hz}, 4 \mathrm{H}), 1.64$ (dq, J = 9.5, 7.6 $\mathrm{Hz}, 4 \mathrm{H}), 1.47$ (q, J = 7.3 Hz, 4H), $1.36(\mathrm{dt}, \mathrm{J}=7.3,3.9 \mathrm{~Hz}, 12 \mathrm{H}), 1.28$ (dt, J = 7.2, 3.8 $\mathrm{Hz}, 8 \mathrm{H}), 0.92$ (ddt, J = 7.1, 4.5, $2.5 \mathrm{~Hz}, 6 \mathrm{H}), 0.89-0.85$ (m, 6H). ${ }^{13} \mathrm{C}$ NMR (100 MHz, $\left.\mathrm{CDCl}_{3}\right) \delta 147.60,141.42,139.39,137.69,137.24,137.22,131.19,130.67,128.18$, 125.29, 124.70, 123.70, 121.98, 32.06, 32.01, 31.98, 31.15, 30.70, 29.87, 29.68, 29.36, 23.05, 23.02, 14.50. HRMS (MALDI-TOF) m/z: $[\mathrm{M}]^{+}$Calcd for $\mathrm{C}_{50} \mathrm{H}_{62} \mathrm{~S}_{6} 854.3176$; Found 854.3161.

\section{Compound 6.}

\section{2,6-bis(3-hexyl-5-iodothiophen-2-yl)-4,8-bis(5-hexylthiophen-2-yl)benzo[1,2-b:4,5}

\section{-b']dithiophene.}

Compound 5 (427 mg, $0.5 \mathrm{mmol}$ ) was dissolved in anhydrous THF (20 mL) under nitrogen atmosphere and was cooled to $-78^{\circ} \mathrm{C}$, then $n$-butyllithium $(3.20 \mathrm{~mL}, 2.0$ mmol, $1.60 \mathrm{M}$ ) was added dropwise via syringe and the solution turned to green. After stirring at this temperature for $2 \mathrm{~h}$, Iodine $(888 \mathrm{mg}, 3.50 \mathrm{mmol})$ was added and the mixture was stirred at $-78^{\circ} \mathrm{C}$ for another $0.5 \mathrm{~h}$. The reaction system was warmed to room temperature and was stirred at room temperature overnight. Water was added and the reaction mixture was extracted three times with $\mathrm{CH}_{2} \mathrm{Cl}_{2}$. The organic layer was separated and dried over $\mathrm{MgSO}_{4}$. After evaporation of the solvent, the crude product was purified on a silica-gel column chromatography with petroleum ether as the eluent. Compound 6 (525 mg, 95\%) was obtained as a light yellow solid. ${ }^{1} \mathrm{H}$ NMR 
(500 MHz, Chloroform-d) $\delta 7.57$ (s, 2H), 7.30 (d, J = 3.5 Hz, 2H), 7.08 (s, 2H), 6.90 $(\mathrm{d}, \mathrm{J}=3.5 \mathrm{~Hz}, 2 \mathrm{H}), 2.91(\mathrm{t}, \mathrm{J}=7.7 \mathrm{~Hz}, 4 \mathrm{H}), 2.77(\mathrm{t}, \mathrm{J}=7.9 \mathrm{~Hz}, 4 \mathrm{H}), 1.78$ (p, J = 7.6 $\mathrm{Hz}, 4 \mathrm{H}), 1.60$ (t, J = 7.6 Hz, 4H), 1.44 (d, J = 14.4 Hz, 4H), 1.35 (d, J = 7.3 Hz, 12H), $1.28(\mathrm{dd}, \mathrm{J}=7.8,4.3 \mathrm{~Hz}, 8 \mathrm{H}), 0.94-0.89(\mathrm{~m}, 6 \mathrm{H}), 0.89-0.84(\mathrm{~m}, 6 \mathrm{H}) .{ }^{13} \mathrm{C}$ NMR $(100$ $\left.\mathrm{MHz}, \mathrm{CDCl}_{3}\right) \delta 147.28,142.65,139.91,138.99,136.73,136.62,136.42,135.87$, $127.74,124.25,123.38,121.88,72.96,31.50,31.48,31.46,30.55,30.18,29.06,29.03$, 28.84, 22.52, 22.50, 14.00, 13.97. HRMS (MALDI-TOF) m/z: [M] Calcd for $\mathrm{C}_{50} \mathrm{H}_{60} \mathrm{I}_{2} \mathrm{~S}_{6}$ 1106.1109; Found 1106.1141.

\section{Compound 7.}

2,2'-((5Z,5'Z)-(4,8-bis(5-hexylthiophen-2-yl)benzo[1,2-b:4,5-b']dithiophene-2,6-di ylidene)bis(4-hexylthiophene-5,2(5H)-diylidene))dimalononitrile. (QTBDT-3H)

A solution of malononitrile $(81.2 \mathrm{mg}, 1.23 \mathrm{mmol})$ in anhydrous DME $(50 \mathrm{~mL})$ under nitrogen atmosphere was cooled down to $0{ }^{\circ} \mathrm{C}$, and Sodium hydride $(100.3 \mathrm{mg}, 60 \%$ dispersed in mineral oil, $2.50 \mathrm{mmol}$ ) was added to the reaction mixture. The reaction mixture was stirred for 30 min with heating autonomously to room temperature. After adding compound $6(350 \mathrm{mg}, 0.316 \mathrm{mmol})$ and $\mathrm{Pd}\left(\mathrm{PPh}_{3}\right)_{4}(37.3 \mathrm{mg}, 0.0322 \mathrm{mmol})$, the resulting suspension was refluxed at $110^{\circ} \mathrm{C}$ overnight. The mixture was cooled to $0{ }^{\circ} \mathrm{C}$ and $50 \mathrm{~mL}$ diluted hydrochloric acid $(2 \mathrm{M})$ was added. The mixture was stirred at $0{ }^{\circ} \mathrm{C}$ for $4 \mathrm{~h}$, then $15 \mathrm{~mL}$ saturated bromine water was added and stirred at $0{ }^{\circ} \mathrm{C}$ for another $30 \mathrm{~min}$. Water was added and the resulting mixture was extracted with $\mathrm{CH}_{2} \mathrm{Cl}_{2}$ three times, the combined organic layers was washed with brine, and dried over $\mathrm{MgSO}_{4}$. After evaporation of the solvent, the residue was purified on a silica-gel column chromatography with $\mathrm{CH}_{2} \mathrm{Cl}_{2}: \mathrm{PE}=2: 1$ to give $55 \mathrm{mg}$ of compound 7 as a purple solid (yield 55\%), which shaped an army green color when was dissolved in solvents. ${ }^{1} \mathrm{H}$ NMR (500 MHz, Dideutero-1,1,2,2-tetrachloroethane) $\delta$ 7.34-7.17 (m, 2H), $6.96(\mathrm{~d}, \mathrm{~J}=3.5 \mathrm{~Hz} 2 \mathrm{H}), 2.97-2.87(\mathrm{~m}, 4 \mathrm{H}), 1.81-1.62(\mathrm{~m}, 8 \mathrm{H}), 1.44-1.26(\mathrm{~m}$, 24H), $0.89 \quad(\mathrm{q}, \quad \mathrm{J}=7.0 \mathrm{~Hz}, \quad 12 \mathrm{H}) . \quad{ }^{13} \mathrm{C} \quad \mathrm{NMR} \quad(100 \mathrm{MHz}$, Dideutero-1,1,2,2-tetrachloroethane) $\delta 149.54,125.05,99.98,53.42,31.55,31.48$, 
31.42, 30.29, 29.21, 28.97, 22.61, 22.51, 14.09, 14.04, 1.02. HRMS (MALDI-TOF) $\mathrm{m} / \mathrm{z}:[\mathrm{M}+\mathrm{H}]^{+}$Calcd for $\mathrm{C}_{56} \mathrm{H}_{61} \mathrm{~N}_{4} \mathrm{~S}_{6}$ 981.3215; Found 981.3180 .

\section{Theoretical calculation}

The diradical factor $\left(y_{i}\right)$ was calculated by the natural orbital occupation number (NOON) of the HOMO and LUMO at the at the UCAM-B3LYP/6-31G $(\mathrm{d}, \mathrm{p})$ level of theory with structure optimized at the UB3LYP/6-31G (d, p). The nucleus independent chemical shift (NICS) calculations with the $\operatorname{NICS}(1)_{\mathrm{zz}}$ value were performed at the GIAO-B3LYP/6-31G (d, p) level. According to the Yamaguchi scheme, ${ }^{\left[{ }^{[2} 2\right]}$ the index for singlet biradical character is expressed as:

$$
y_{i}=1-\frac{2 T i}{1+T i^{2}}
$$

$T_{i}$ in the formula above is the orbital overlap value based on the corresponding orbital pairs and it could be calculated by the following formula:

$$
T_{i}=\frac{n_{\text {HOMO }}-n_{L U M O}}{2}
$$

\section{Variable-temperature NMR experiment}

Approximately $5 \mathrm{mg}$ of QBDT and QTBDT-3H were dissolved in chloroform $\left(\mathrm{CDCl}_{3}\right)$ and Dideutero-1,1,2,2-tetrachloroethane $\left(\mathrm{C}_{2} \mathrm{D}_{2} \mathrm{Cl}_{4}\right)$, respectively. The solution was transferred to the J-Young tube and the spectrum was recorded with a temperature gradient range from -10 to $40{ }^{\circ} \mathrm{C}$ for QBDT and -10 to $80{ }^{\circ} \mathrm{C}$ for QTBDT-3H. 


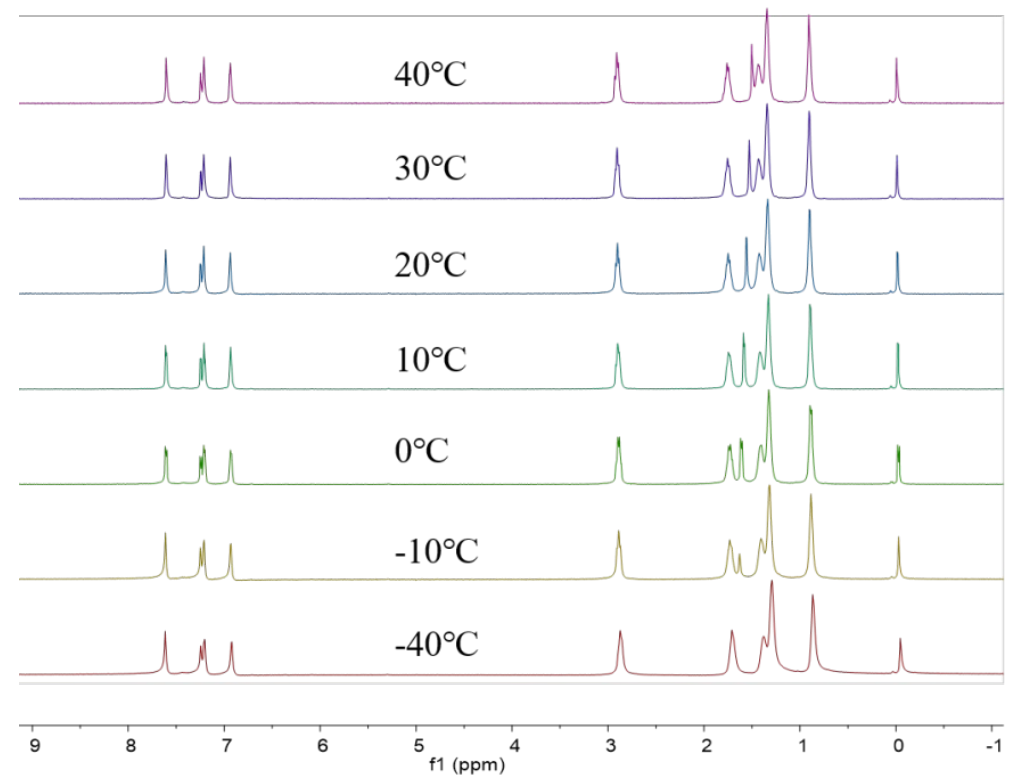

Figure S1. ${ }^{1} \mathrm{H}$ NMR spectrum of QBDT recorded in $\mathrm{CDCl}_{3}$ at $-40,-10,0,10,20,30$ and $40{ }^{\circ} \mathrm{C}(500 \mathrm{MHz})$.

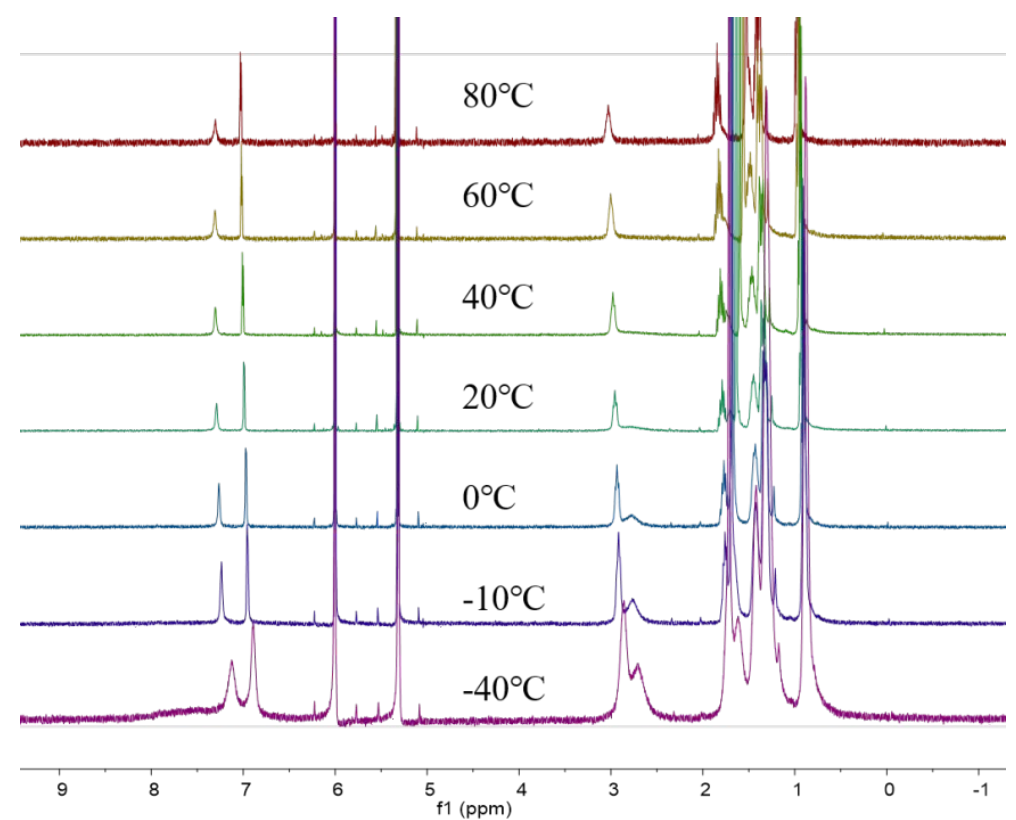

Figure S2. ${ }^{1} \mathrm{H}$ NMR spectrum of QTBDT-3H recorded in $\mathrm{C}_{2} \mathrm{D}_{2} \mathrm{Cl}_{4}$ at $-40,-10,0,20$, 40,60 and $80^{\circ} \mathrm{C}(500 \mathrm{MHz})$.

\section{SQUID measurement}

The magnetic susceptibility was measured with MPMS XL-7 Quantum Design SQUID magnetometer in the temperature range of 2-350 K. With a mass of $18.9 \mathrm{mg}$, powder of QTBDT-3H was set in a capsule. And the measurement was performed within an external magnetic field of $0.1 \mathrm{~T}$. The obtained experimental data $\left(\chi_{\mathrm{m}} \mathrm{T}\right.$ vs. T) 
were fitted using the classical Bleaney-Bowers equation with an antiferromagentic $\mathrm{S}$ $=1 / 2$ dimer ${ }^{[\mathrm{S} 3]}$

$$
\chi=\frac{2 N \beta^{2} g^{2}}{3 k T}\left[1+\frac{1}{3} \exp \left(\frac{J_{s-t}}{k T}\right)\right]^{-1}
$$

\section{UV-vis absorption spectrum}

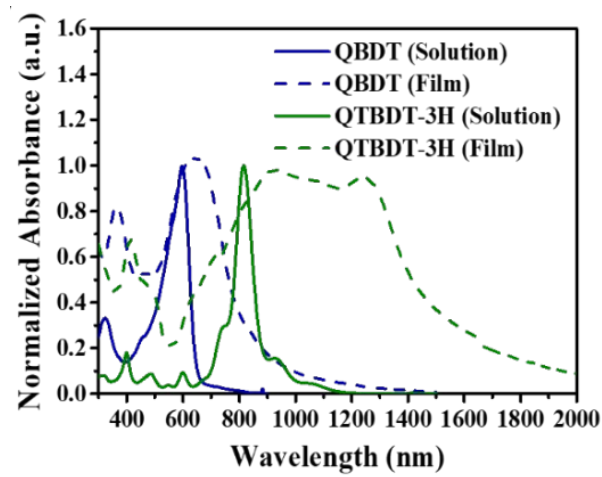

Figure S3. The absorption spectrum in the solution and film state of QBDT and QTBDT-3H.

\section{Stability tests}

The spectrum (absorption intensity at the $816 \mathrm{~nm}$ ) change over time of the QTBDT-3H solution $\left(10^{-5} \mathrm{M}\right)$ was recorded. The half-life time $\left(\tau_{1 / 2}\right)$ of QTBDT-3H was estimated to be 25 days according to the linear regression with extrapolating to $\mathrm{A}_{\mathrm{t}} / \mathrm{A}_{0}=0.50$.
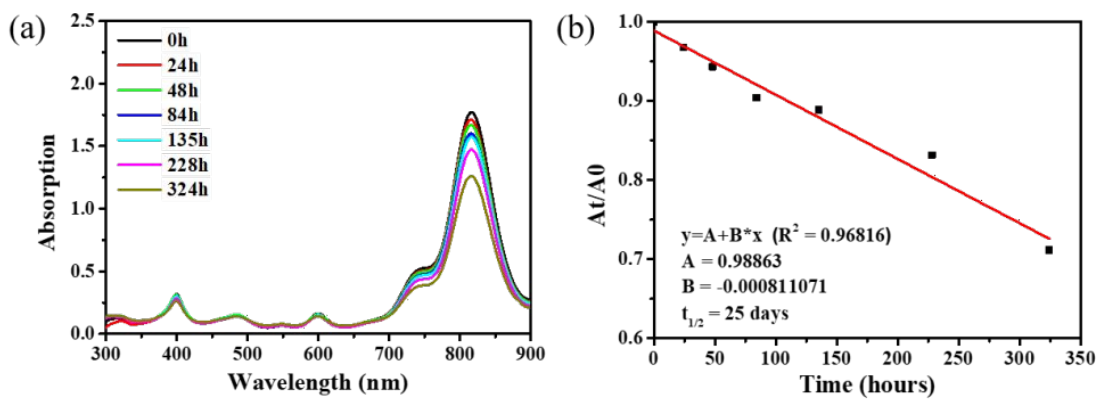

Figure S4. (a) Change of UV-vis absorption spectrum with time, (b) Plot of At/A0 proportion and the equation of linear regression. 


\section{OTFT device fabrication and performance}

Bottom-gate top-contact (BGTC) OTFT devices were fabricated as following: A heavily doped n-type $\mathrm{Si}$ wafer with $300 \mathrm{~nm} \mathrm{SiO}{ }_{2}\left(\mathrm{C}_{\mathrm{i}}=11.5 \mathrm{n} \mathrm{Fcm}^{-2}\right)$ as the dielectric layer was used. The cleaned $\mathrm{SiO}_{2}$ surface was subsequently treated with OTS in a vacuum oven for $3 \mathrm{~h}$. The semiconducting layer was then deposited by spin-coating of the QBDT or QTBDT-3H solution (5 or $8 \mathrm{mg} / \mathrm{mL}$ in chloroform) at $5000 \mathrm{rpm}$ for 1 min. After thermal annealing at $80,100,110,120^{\circ} \mathrm{C}$ for $10 \mathrm{~min}$, the source and drain electrodes were deposited on semiconducting layer by vacuum evaporation with a shadow mask $(W / L=2000 \mu \mathrm{m} / 100 \mu \mathrm{m})$. All the devices were tested in ambient condition by Keithley 4200SCS semiconductor analyzer.

Table S1. OFET characteristics of QBDT and QTBDT-3H.

\begin{tabular}{|c|c|c|c|c|c|c|c|}
\hline Compound & $\begin{array}{c}\text { Annealing } \\
\text { temperature } \\
\left({ }^{\circ} \mathrm{C}\right)\end{array}$ & $\begin{array}{c}\mu_{\mathrm{e}}^{a} \\
\left(\mathrm{~cm}^{2} \mathrm{~V}^{-1} \mathrm{~s}^{-1}\right)\end{array}$ & $I_{\mathrm{ON}} / I_{\mathrm{OFF}}$ & $\begin{array}{l}V_{\text {th }} \\
(\mathrm{V})\end{array}$ & $\begin{array}{c}\mu_{\mathrm{h}}{ }^{a} \\
\left(\mathrm{~cm}^{2} \mathrm{~V}^{-1} \mathrm{~s}^{-1}\right)\end{array}$ & $I_{\mathrm{ON}} / I_{\mathrm{OFF}}$ & $\begin{array}{l}V_{\text {th }} \\
(\mathrm{V})\end{array}$ \\
\hline \multirow{4}{*}{ QBDT } & As cast & $\begin{array}{c}0.0051 \\
(0.0067)\end{array}$ & $10^{3}$ & $5 \pm 1$ & & & \\
\hline & 80 & $\begin{array}{c}0.018 \\
(0.021)\end{array}$ & $10^{5}$ & $5 \pm 1$ & & & \\
\hline & 100 & $\begin{array}{l}0.014 \\
(0.016)\end{array}$ & $10^{5}$ & $5 \pm 1$ & & & \\
\hline & 120 & $\begin{array}{c}0.0073 \\
(0.0076)\end{array}$ & $10^{5}$ & $5 \pm 1$ & & & \\
\hline \multirow{5}{*}{ QTBDT-3H } & As cast & $\begin{array}{c}0.085 \\
(0.098)\end{array}$ & $10^{2}$ & $14 \pm 4$ & $\begin{array}{c}0.065 \\
(0.073)\end{array}$ & $10^{2}$ & $-25 \pm 3$ \\
\hline & 80 & $\begin{array}{c}0.12 \\
(0.19)\end{array}$ & $10^{2}$ & $16 \pm 4$ & $\begin{array}{c}0.1 \\
(0.13)\end{array}$ & $10^{2}$ & $-27 \pm 1$ \\
\hline & 100 & $\begin{array}{l}0.12 \\
(0.14)\end{array}$ & $10^{2}$ & $15 \pm 1$ & $\begin{array}{l}0.089 \\
(0.12)\end{array}$ & $10^{2}$ & $-27 \pm 2$ \\
\hline & 110 & $\begin{array}{c}0.28 \\
(0.32)\end{array}$ & $10^{3}$ & $16 \pm 4$ & $\begin{array}{l}0.089 \\
(0.16)\end{array}$ & $10^{2}$ & $-27 \pm 1$ \\
\hline & 120 & $\begin{array}{l}0.096 \\
(0.1)\end{array}$ & $10^{2}$ & $17 \pm 3$ & $\begin{array}{l}0.092 \\
(0.13)\end{array}$ & $10^{2}$ & $-24 \pm 4$ \\
\hline
\end{tabular}

${ }^{a}$ Average mobilities, with the maximum mobilities shown in parentheses. More than 20 devices were characterized at each annealing temperature of QBDT and QTBDT-3H (see Figure S5-S9). All devices were measured under ambient conditions. 

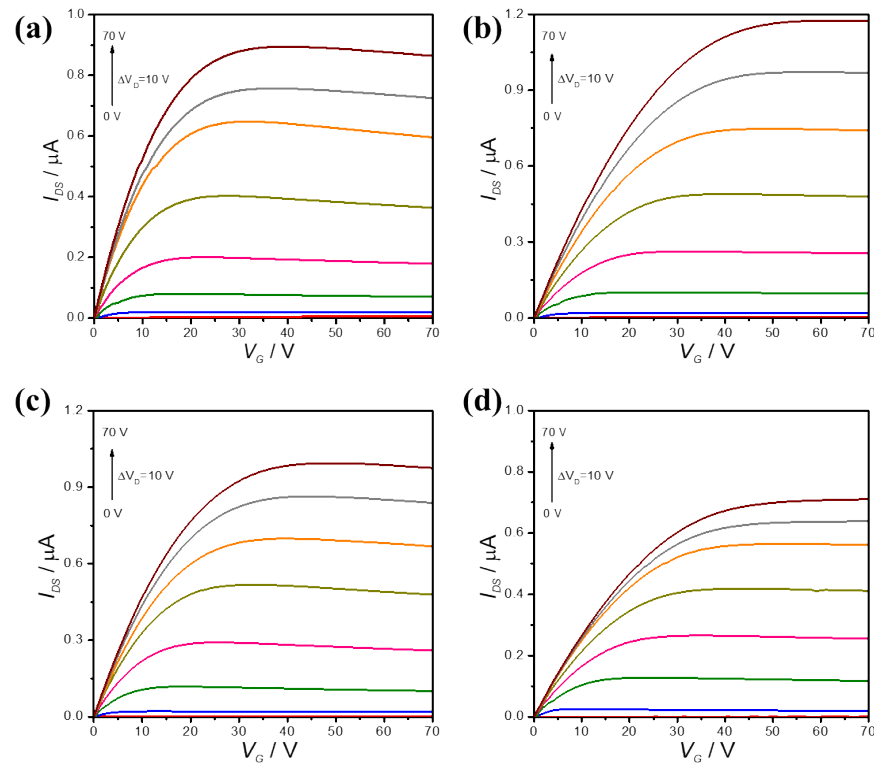

Figure S5. Output curves of OFETs based on semiconductors of QBDT (a-d: a, As cast; b, $80{ }^{\circ} \mathrm{C}$; c, $\left.100{ }^{\circ} \mathrm{C} ; \mathrm{d}, 120^{\circ} \mathrm{C}\right)$.
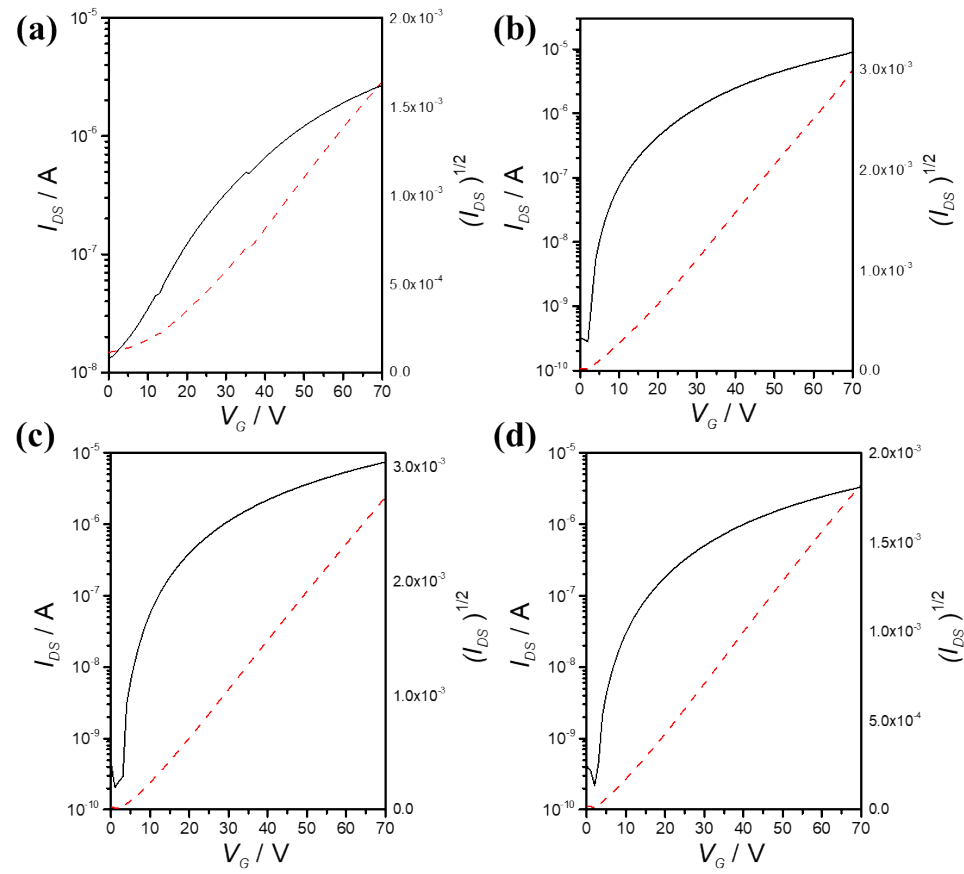

Figure S6. Transfer curves $\left(V_{\mathrm{DS}}=70 \mathrm{~V}\right)$ of OFETs based on QBDT (a-d: a, As cast; b, $80{ }^{\circ} \mathrm{C}$; c, $100{ }^{\circ} \mathrm{C} ; \mathrm{d}, 120^{\circ} \mathrm{C}$ ). 

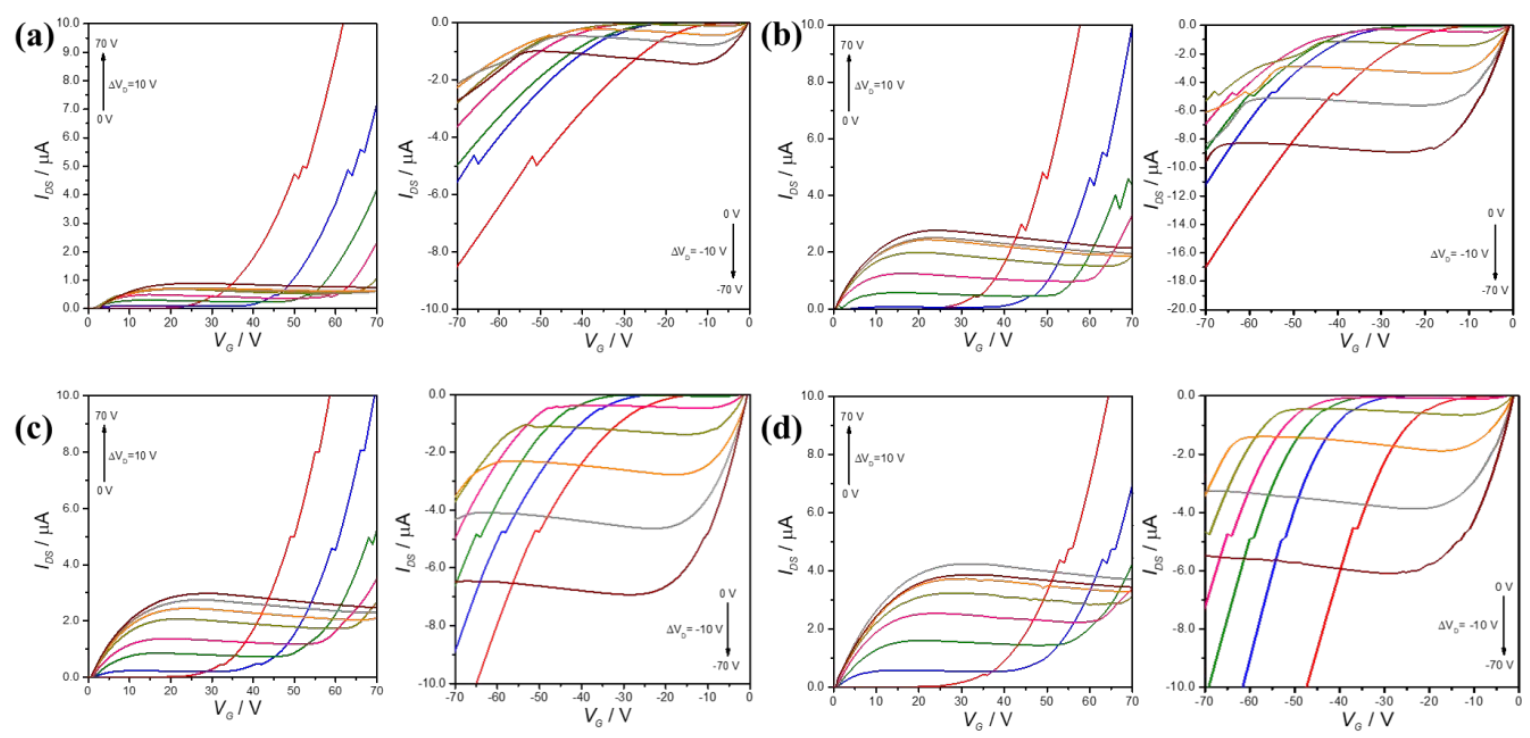

Figure S7. Output curves of OFETs based on QTBDT-3H (a-d: a, As cast; b, $80{ }^{\circ} \mathrm{C}$; c, $\left.100^{\circ} \mathrm{C} ; \mathrm{d}, 120^{\circ} \mathrm{C}\right)$.
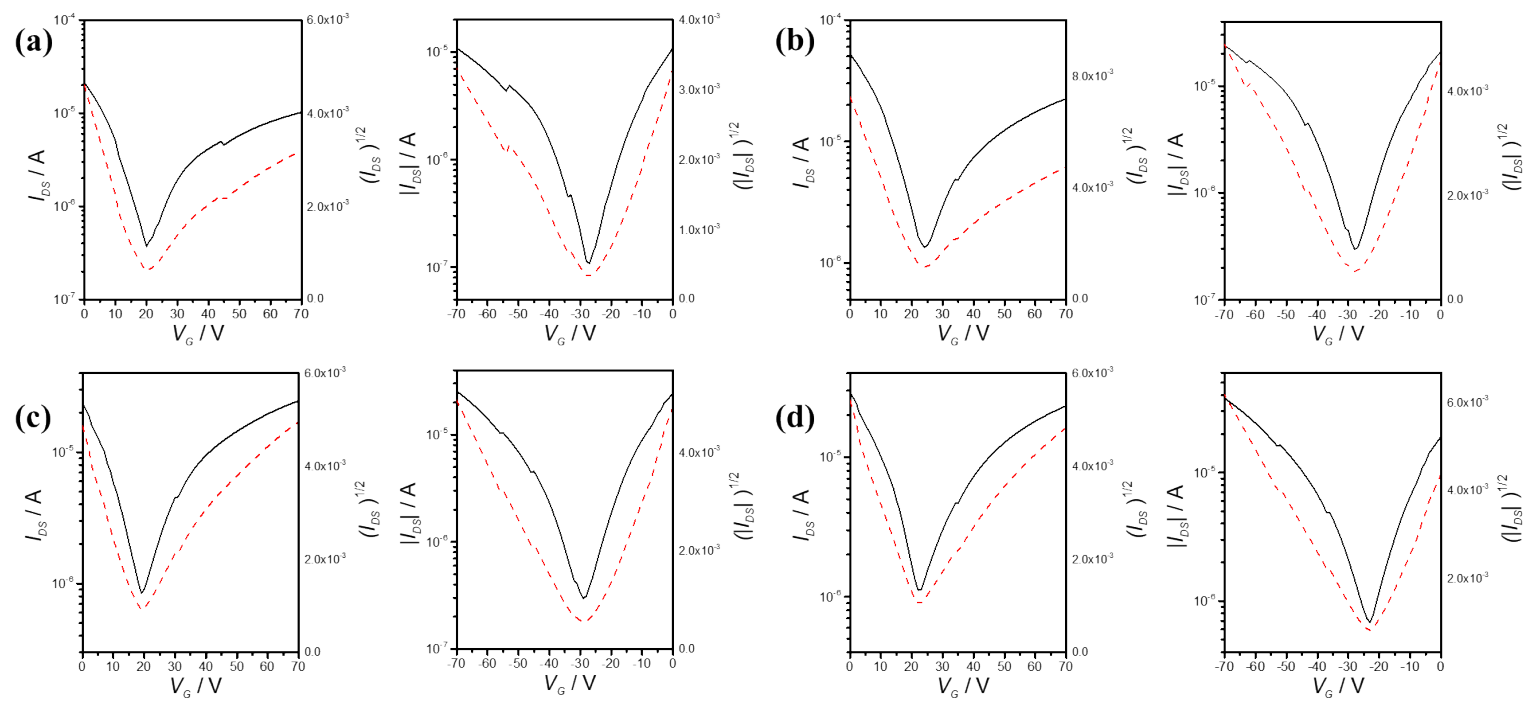

Figure S8. N-channel $\left(V_{\mathrm{DS}}=70 \mathrm{~V}\right)$ and p-channel $\left(V_{\mathrm{DS}}=-70 \mathrm{~V}\right)$ transfer curves of OFETs based on QTBDT-3H (a-d: a, As cast; b, $80{ }^{\circ} \mathrm{C}$; c, $100^{\circ} \mathrm{C}$; d, $120^{\circ} \mathrm{C}$ ).

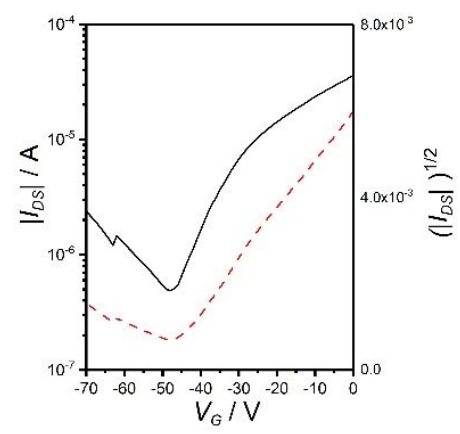

Figure S9. P-channel transfer curve of OFET device based on QBDT-3H (annealed 
at $110^{\circ} \mathrm{C}$ ) measured in vacuum.

\section{AFM images}
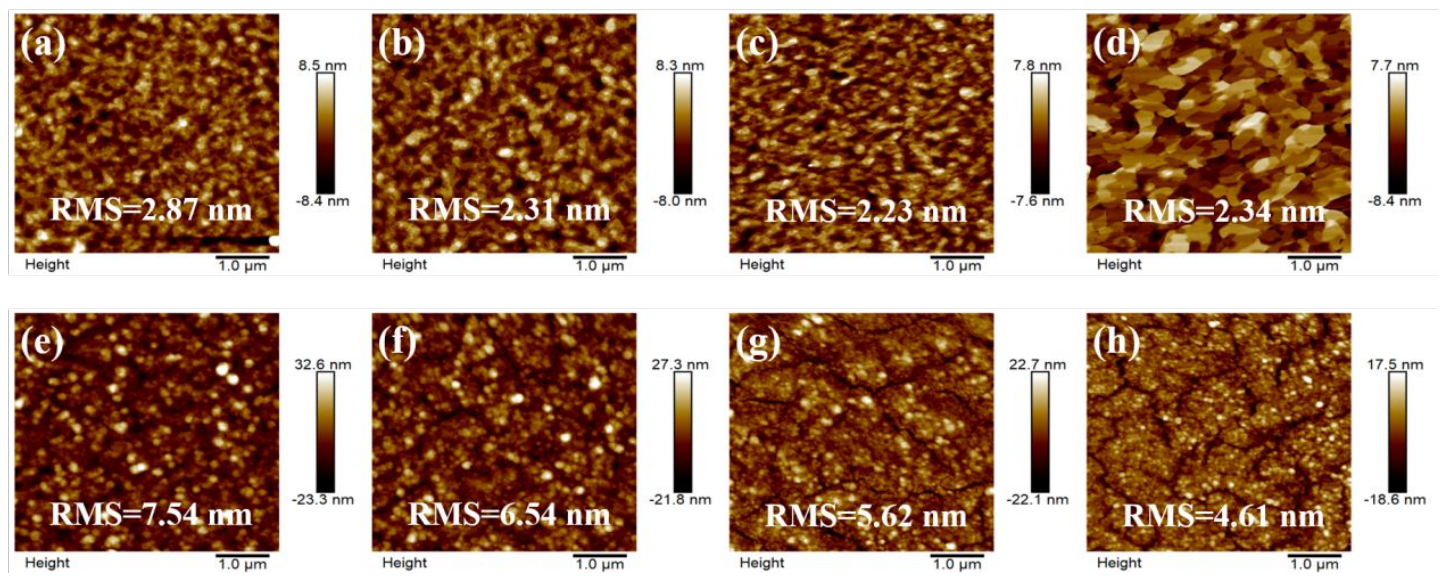

Figure S10. AFM images of thin films based on QBDT (a-d) and QTBDT-3H (e-h) after thermal annealing at temperature of $\mathrm{rt}(\mathrm{a}, \mathrm{e}), 80^{\circ} \mathrm{C}(\mathrm{b}, \mathrm{f}), 100^{\circ} \mathrm{C}(\mathrm{c}, \mathrm{g})$, and 120 ${ }^{\circ} \mathrm{C}(\mathrm{d}, \mathrm{h})$, respectively.

\section{$10 .{ }^{1} \mathrm{H}$ and ${ }^{13} \mathrm{C}$ NMR spectrum}

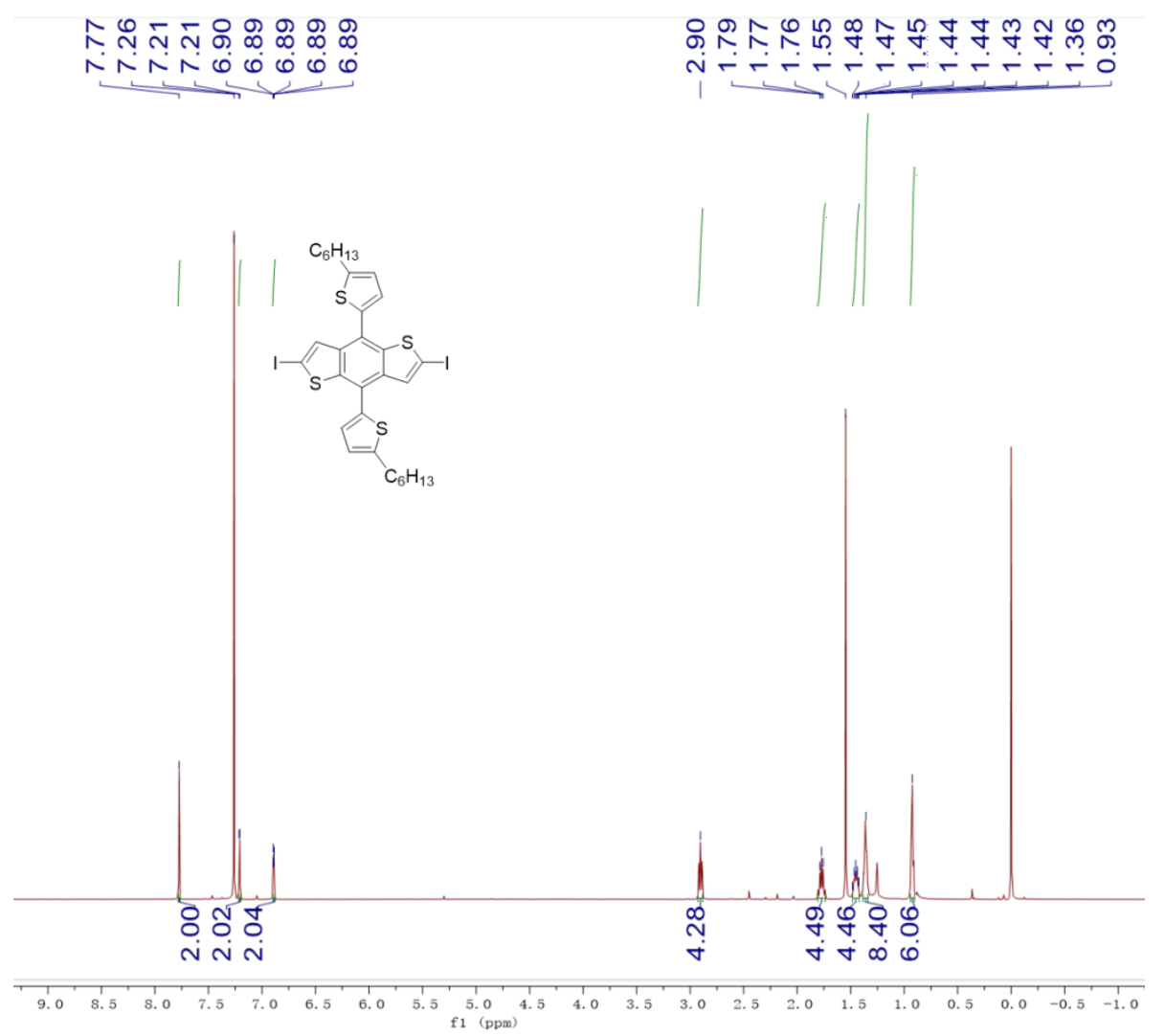


Figure S11. ${ }^{1} \mathrm{H}$ NMR spectrum for compound $2\left(\mathrm{CDCl}_{3}, 500 \mathrm{MHz}\right)$.

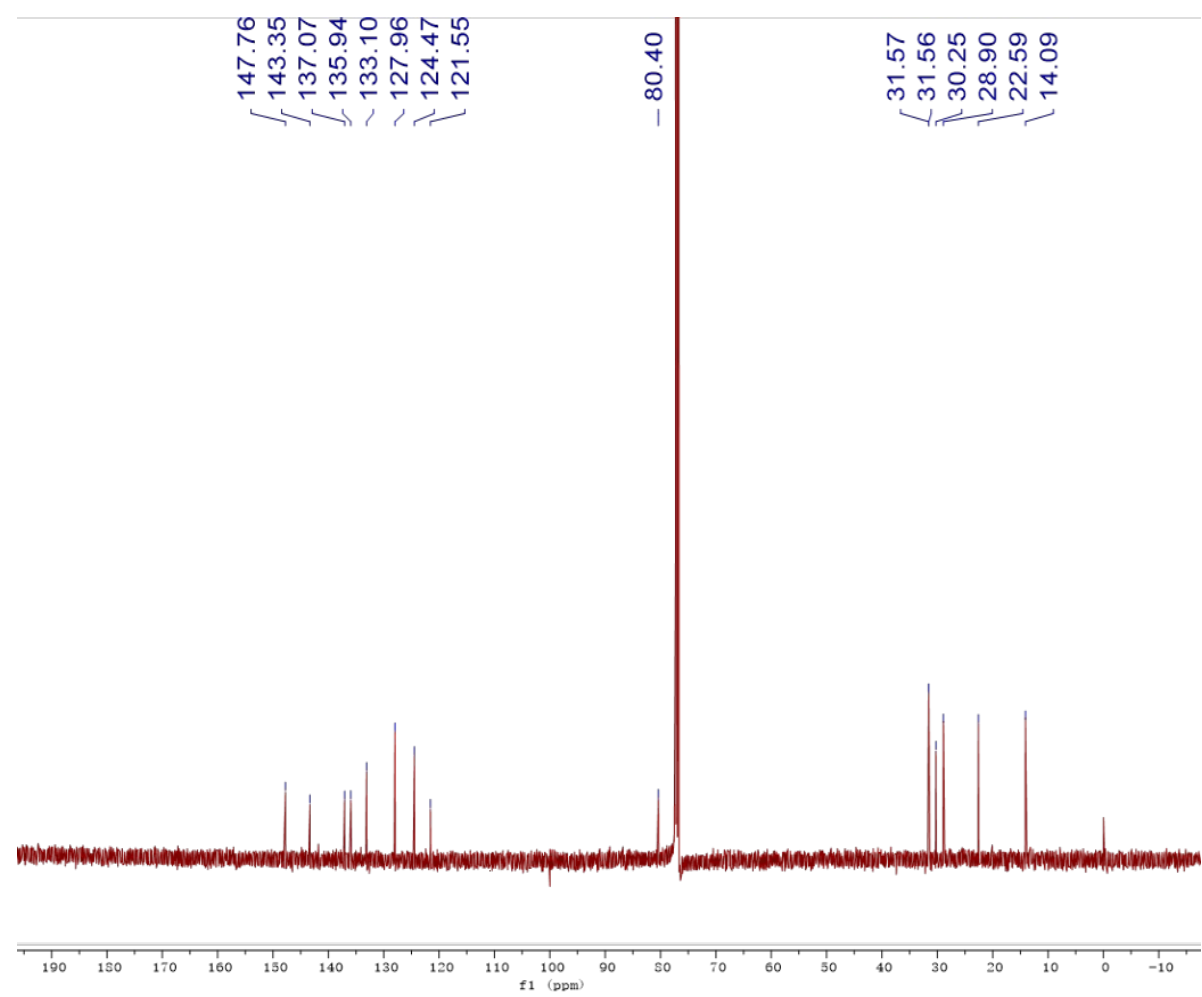

Figure S12. ${ }^{13} \mathrm{C}$ NMR spectrum for compound $2\left(\mathrm{CDCl}_{3}, 100 \mathrm{MHz}\right)$.

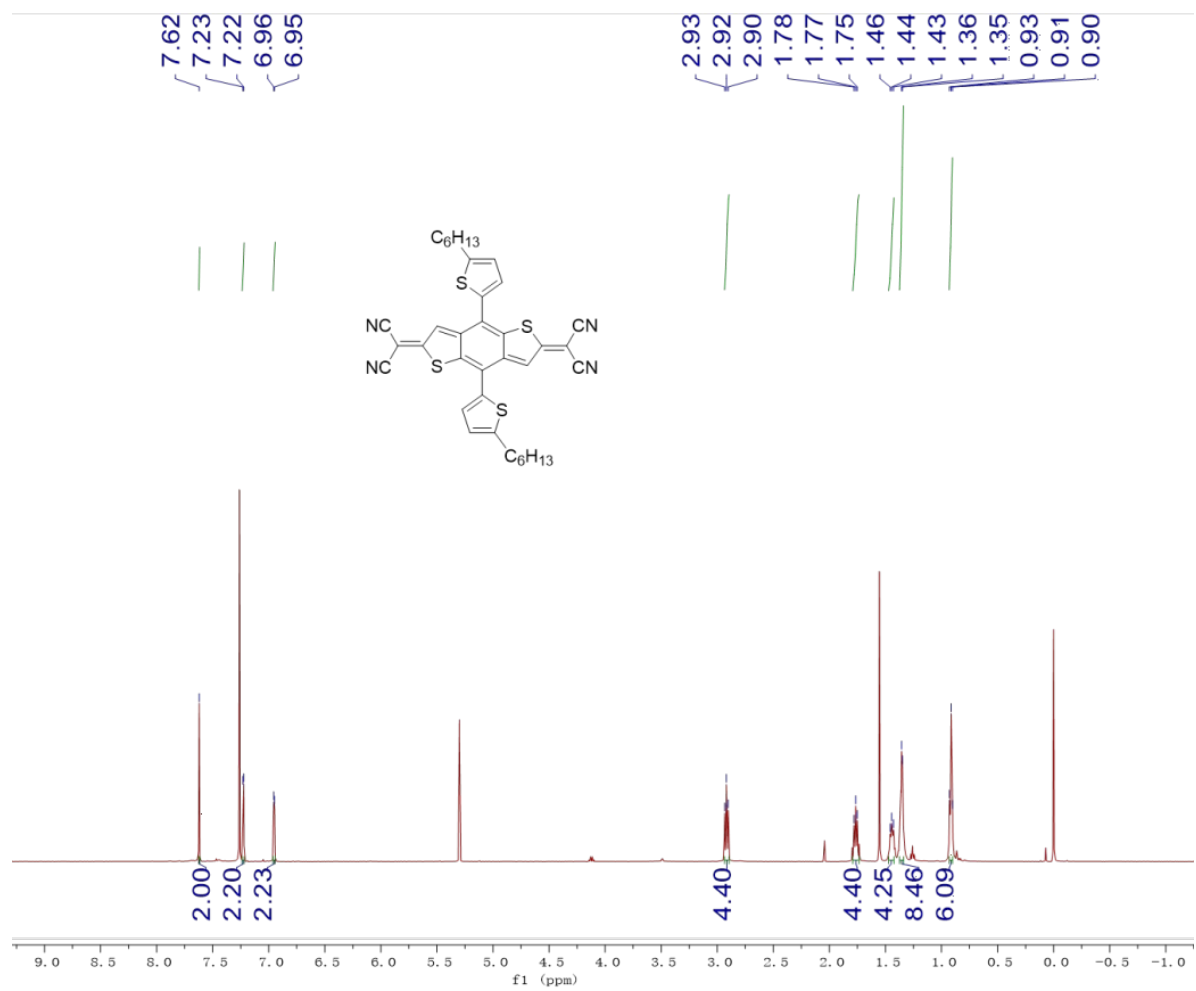

Figure S13. ${ }^{1} \mathrm{H}$ NMR spectrum for compound 3 (QBDT) $\left(\mathrm{CDCl}_{3}, 500 \mathrm{MHz}\right)$. 


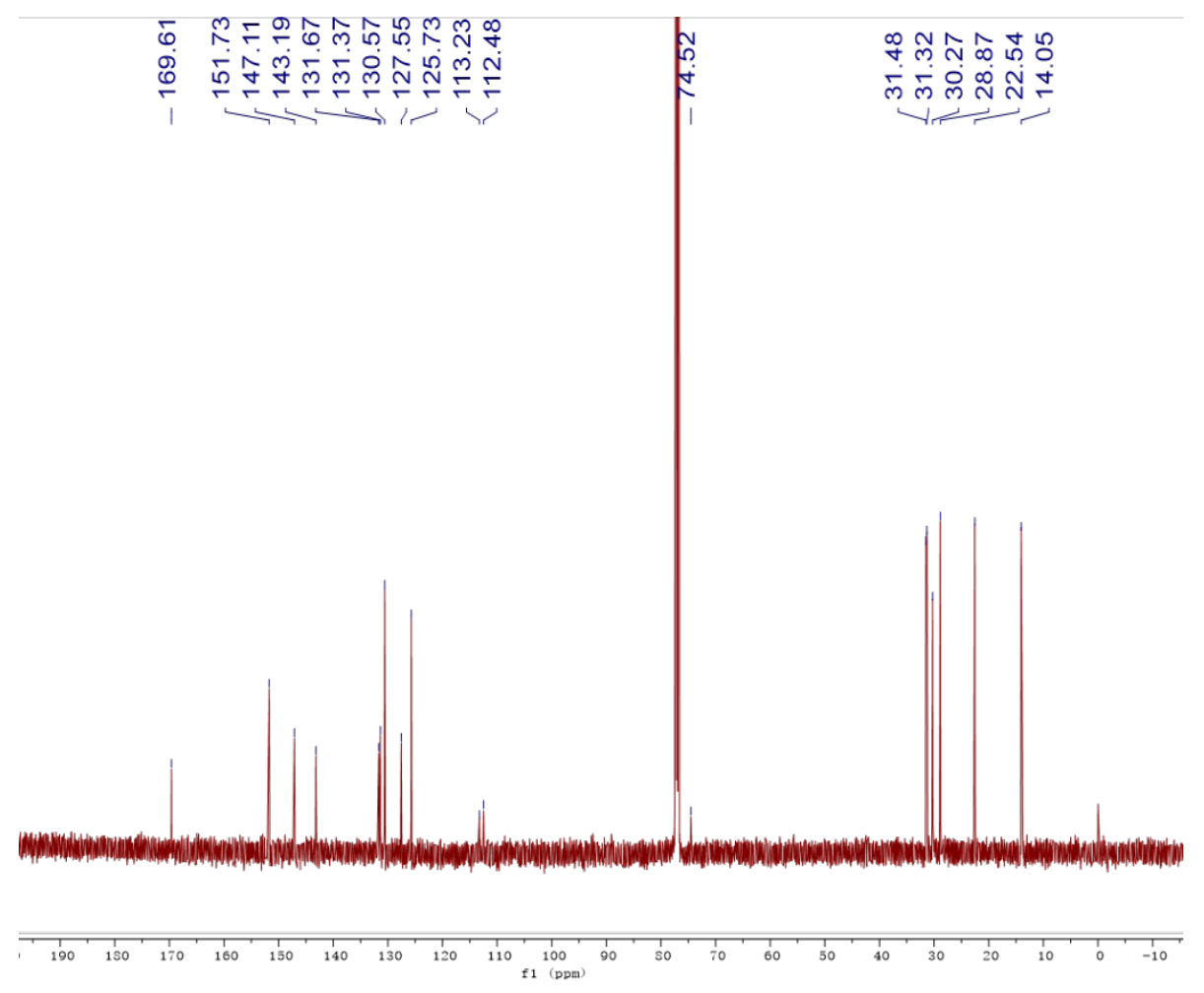

Figure S14. ${ }^{13} \mathrm{C}$ NMR spectrum for compound 3 (QBDT) $\left(\mathrm{CDCl}_{3}, 100 \mathrm{MHz}\right)$.

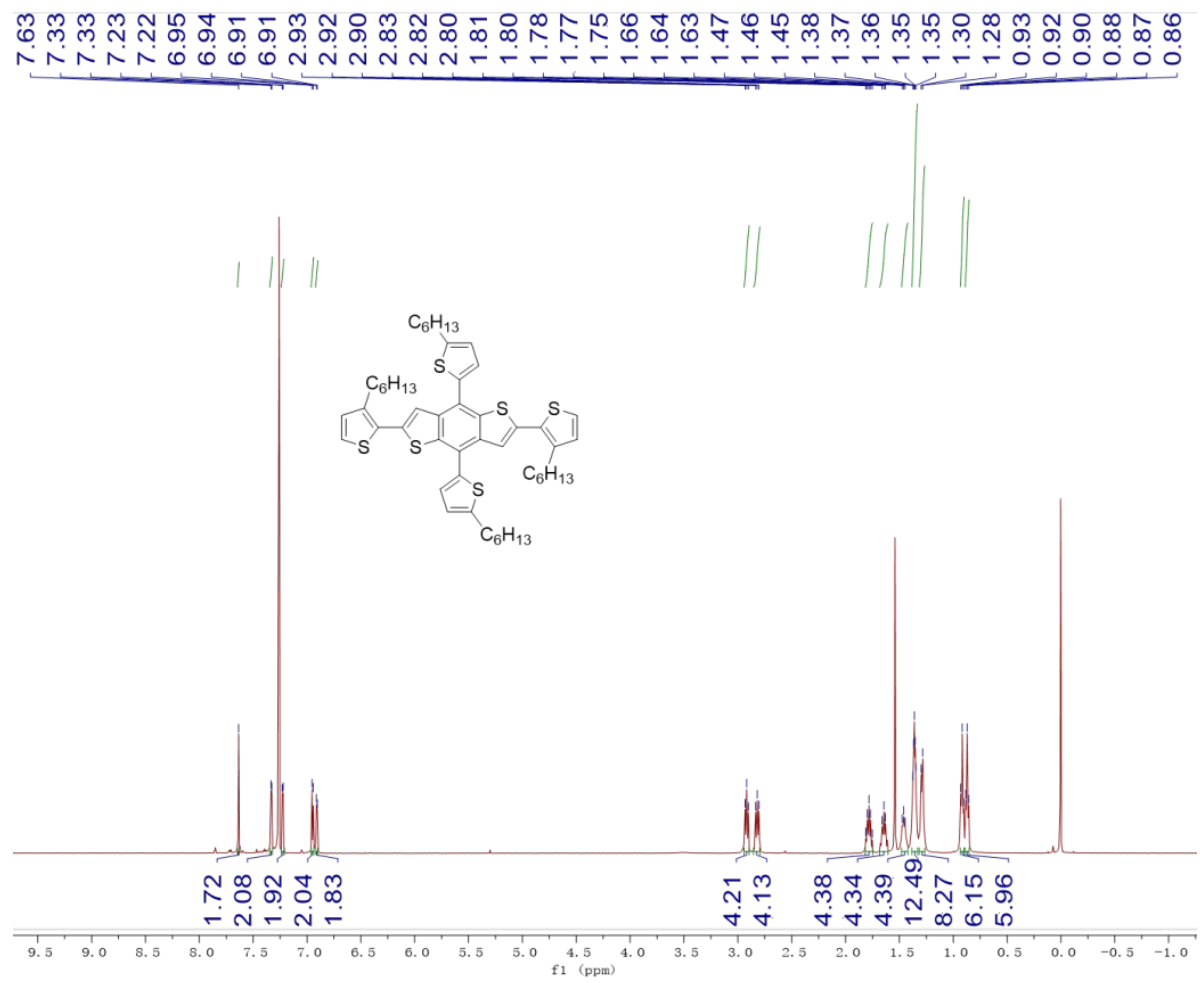

Figure S15. ${ }^{1} \mathrm{H}$ NMR spectrum for compound $5\left(\mathrm{CDCl}_{3}, 500 \mathrm{MHz}\right)$. 


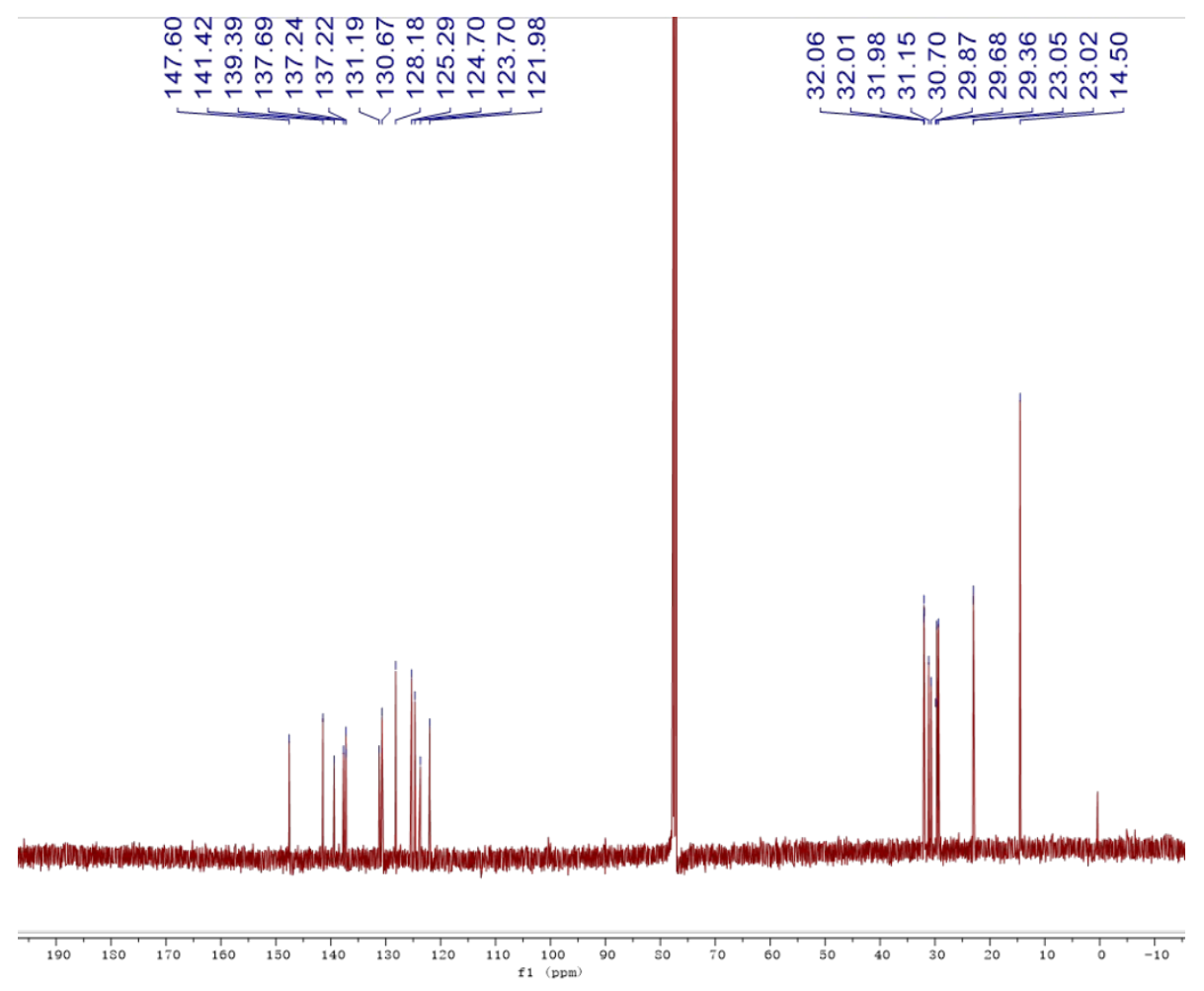

Figure S16. ${ }^{13} \mathrm{C}$ NMR spectrum for compound $5\left(\mathrm{CDCl}_{3}, 100 \mathrm{MHz}\right)$.

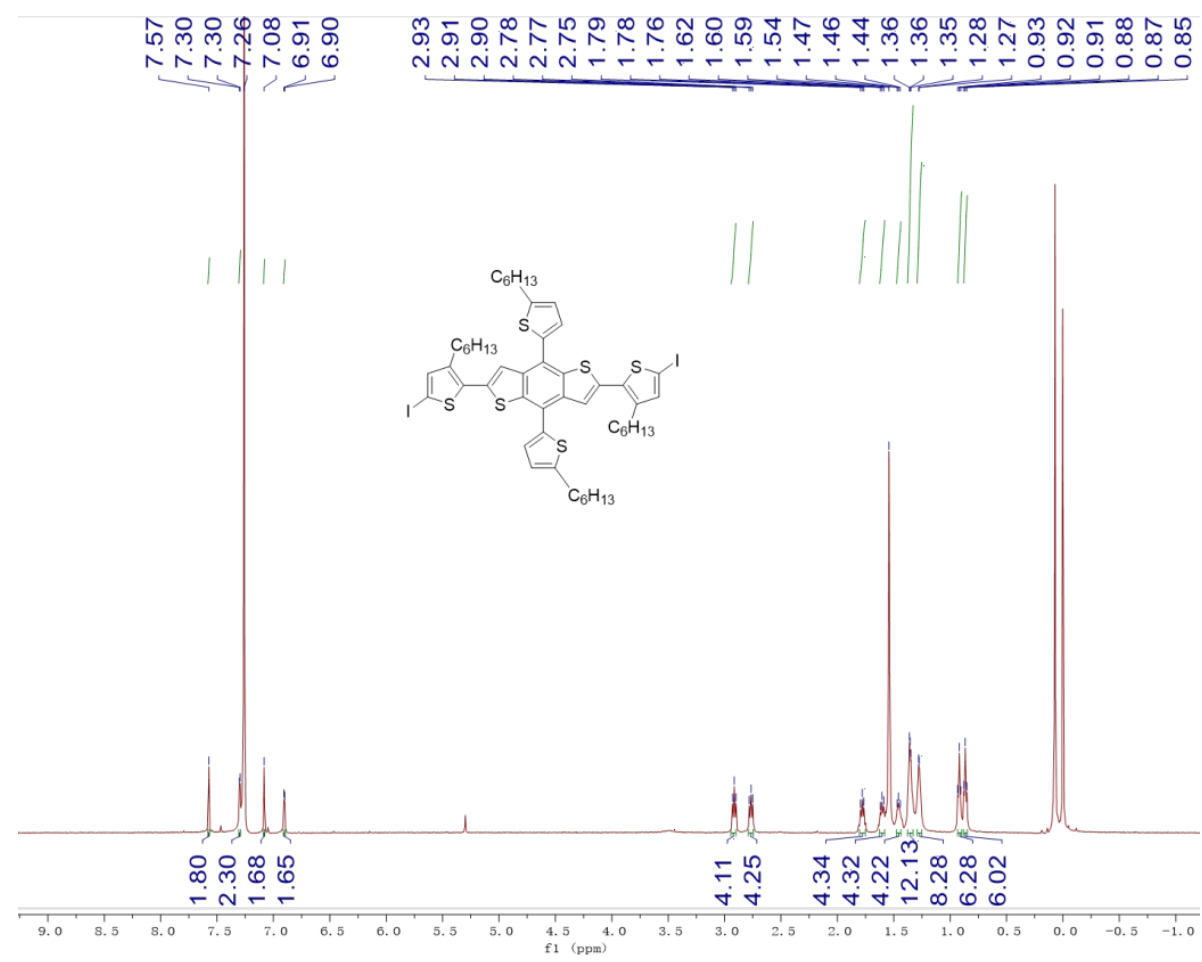

Figure S17. ${ }^{1} \mathrm{H}$ NMR spectrum for compound $6\left(\mathrm{CDCl}_{3}, 500 \mathrm{MHz}\right)$. 


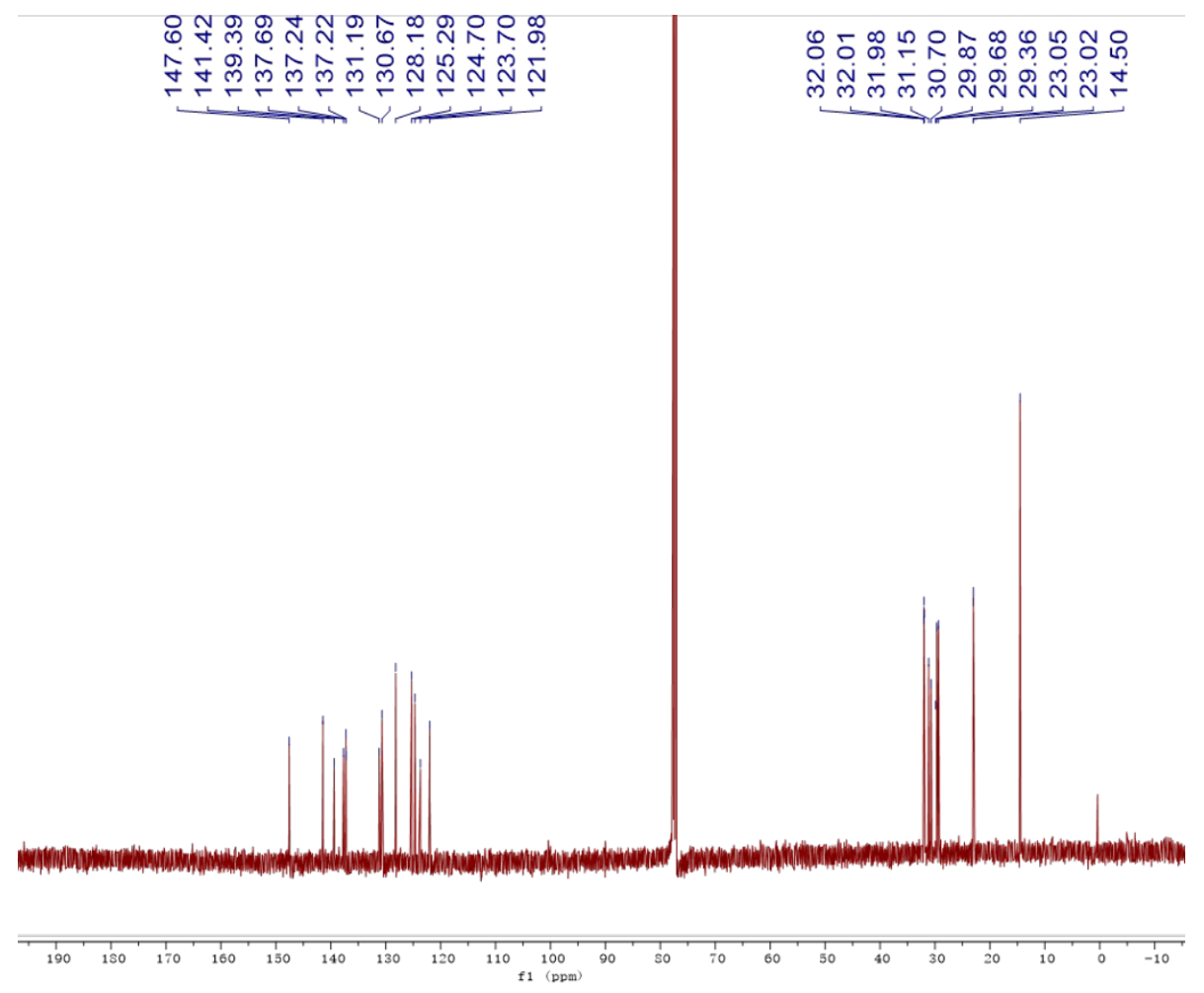

Figure S18. ${ }^{13} \mathrm{C}$ NMR spectrum for compound $6\left(\mathrm{CDCl}_{3}, 100 \mathrm{MHz}\right)$.

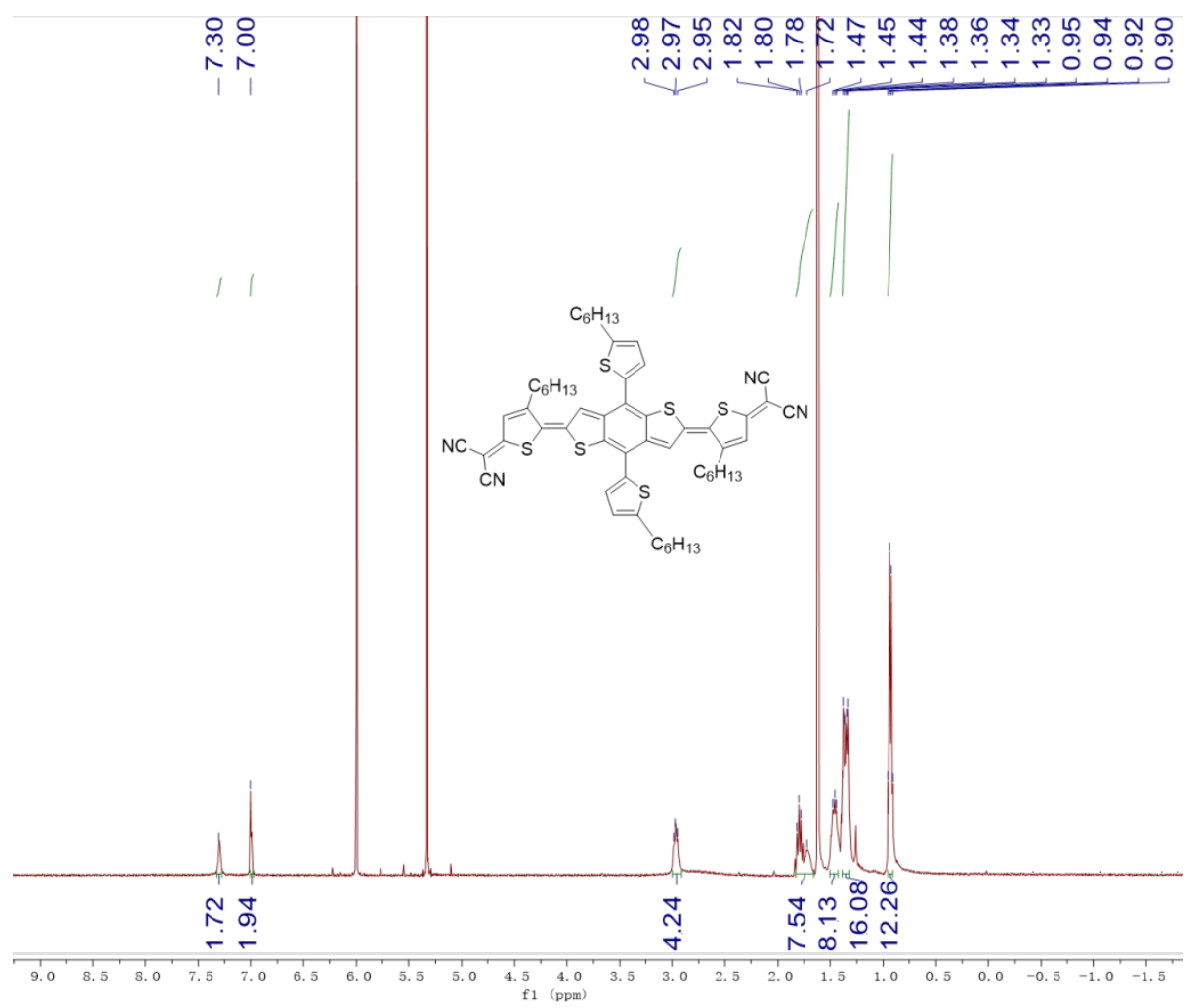

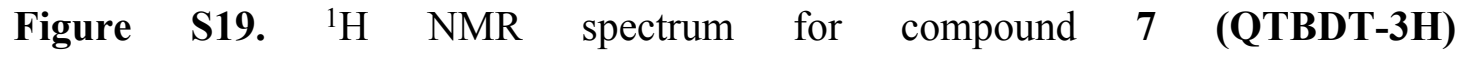
(Dideutero-1,1,2,2-tetrachloroethane, $500 \mathrm{MHz}$ ). 


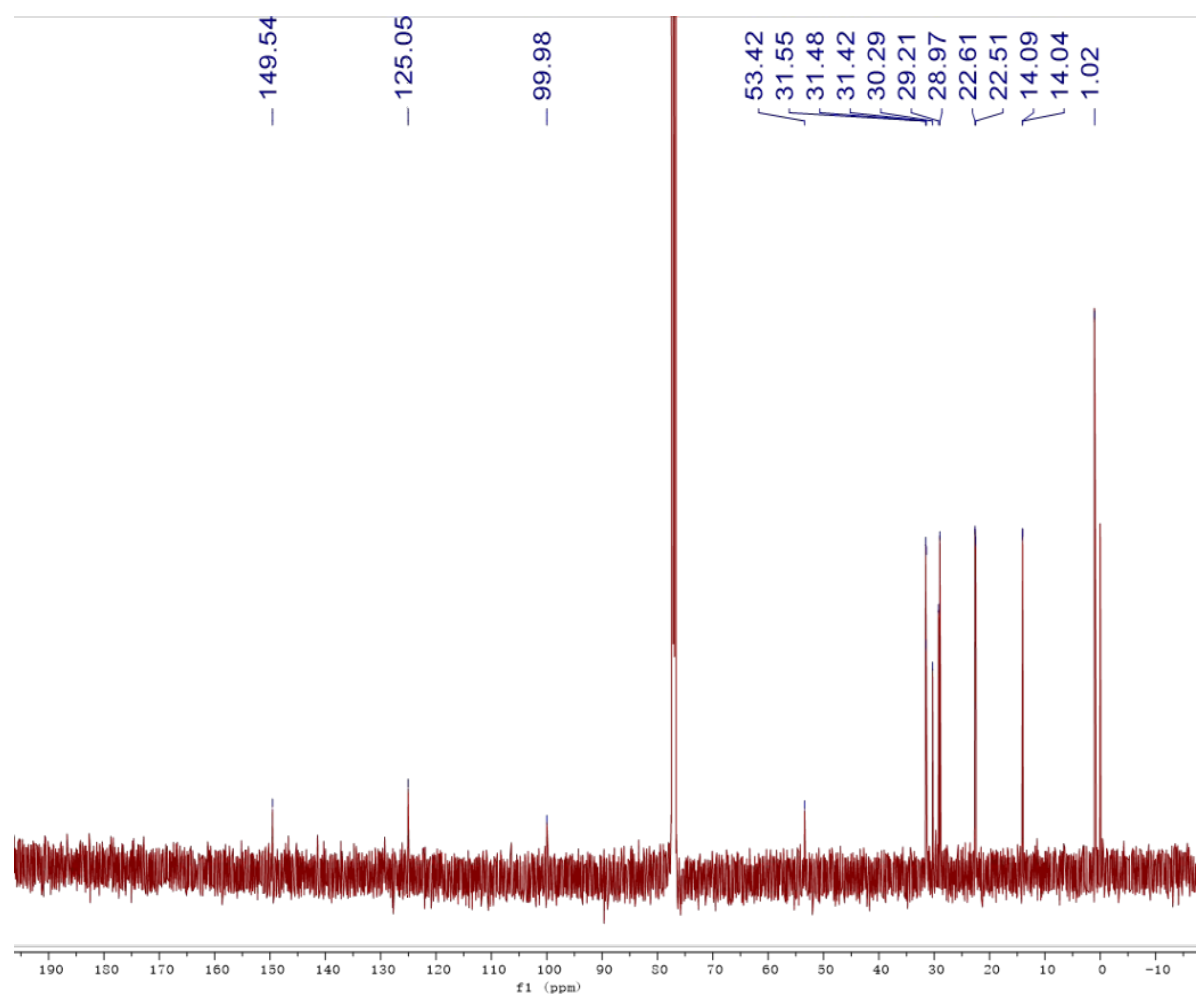

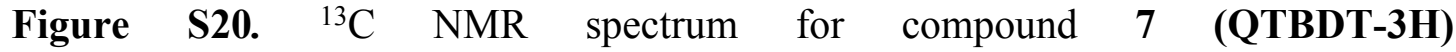
(Dideutero-1,1,2,2-tetrachloroethane, $100 \mathrm{MHz}$ ). 


\section{MALDI-TOF Mass spectrum}

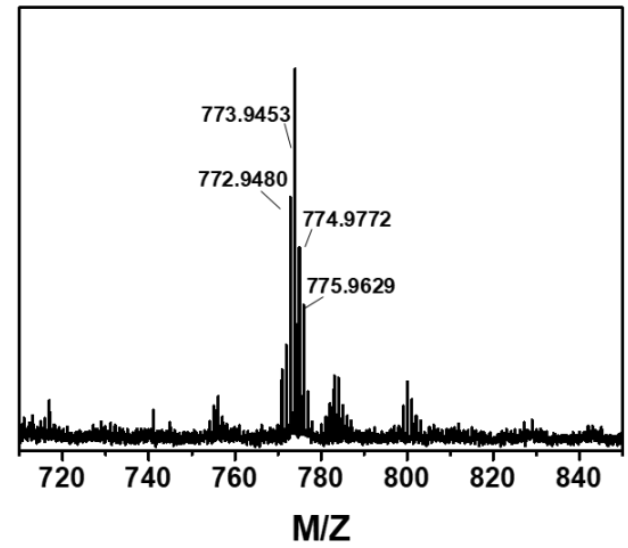

Figure S21. MALDI-TOF Mass Spectrum for compound 2.

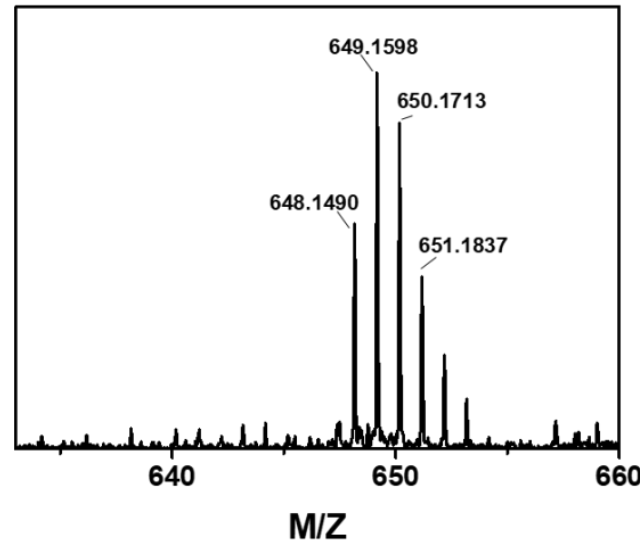

Figure S22. MALDI-TOF Mass Spectrum for compound 3 (QBDT).

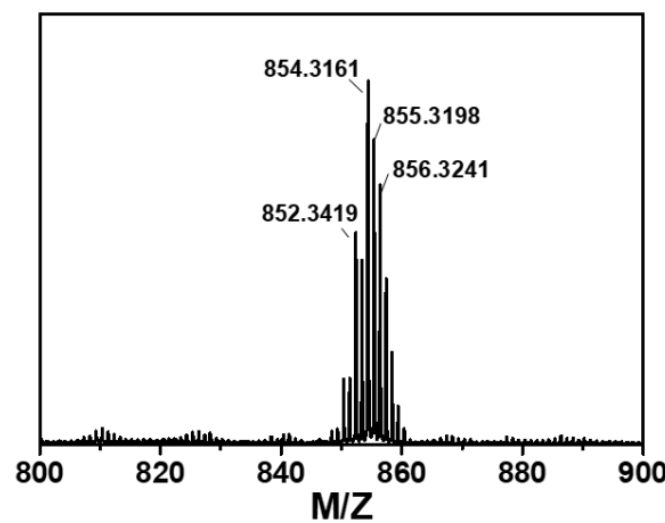

Figure S23. MALDI-TOF Mass Spectrum for compound 5. 


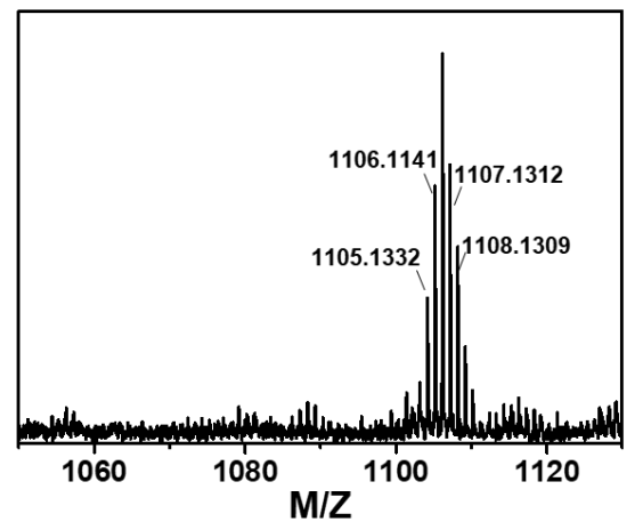

Figure S24. MALDI-TOF Mass Spectrum for compound 6.

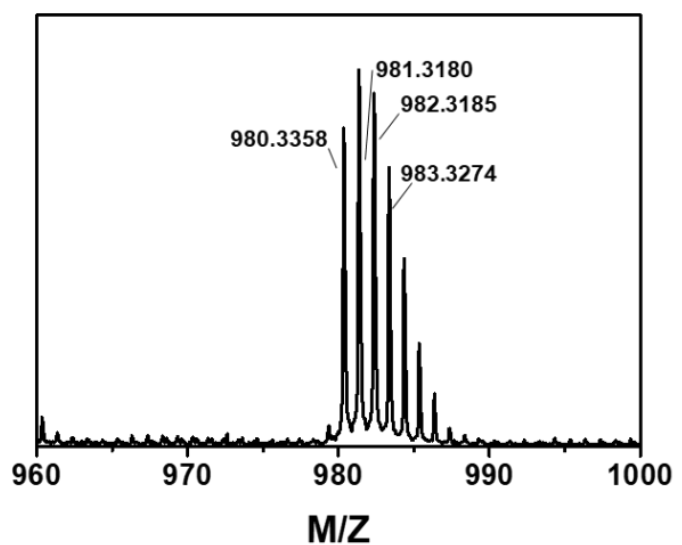

Figure S25. MALDI-TOF Mass Spectrum for compound 7 (QTBDT-3H).

\section{References}

S1. Zhang, Y.; Gao, L.; He, C.; Sun, Q. J.; Li, Y. F. Poly. Chem. 2013, 4, 1474-1481.

S2. Doehnert, D.; Koutecky, J. J. Am. Chem. Soc. 1980, 102, 1789-1796.

S3. Bleaney, B.; Bowers, K. D. Proc, R. Soc. London Ser. A 1952, 214, 451-465. 